\title{
Analysis of erosion hazardous level and sedimentation in Manna Watershed, Bengkulu Province Indonesia
}

\author{
Khairul Amri ${ }^{1, \star}$, Muhammad Faiz Barchia ${ }^{2}$, Yuzuar Aprizal ${ }^{3}$ \\ ${ }^{1,3}$ Civil Engineering Department Faculty of Engineering, University of Bengkulu, 38371 Bengkulu, Indonesia \\ ${ }^{2}$ Soil Science Department Faculty of Agriculture, University of Bengkulu, 38371 Bengkulu, Indonesia
}

\begin{abstract}
The research purposeis to analyze erosion hazardous level and sedimentation on Manna watershed, Bengkulu Province. The research area geographically lies between 102 $51^{\prime} 38.2^{\prime \prime}-103^{\circ} 10^{\prime} 57.8^{\prime \prime}$ East., and $4^{\circ} 0^{\prime} 39.6^{\prime \prime}-4^{\circ} 29^{\prime} 38.0^{\prime \prime}$ South covering 72,071.9 ha. Potential erosion yield and level were calculated by applying Universal Soil Loss Equation, and spatial analysis of the erosion was done using ArcGIS. The potential erosion in Manna watershed was classified as moderate hazardous level of $12,442,368.12$ tons $\mathrm{yr}^{-1}$ or similar to 170.68 tons $\mathrm{ha}^{-1} \mathrm{yr}^{-1}$. Moderate to high level Soil erosion covered areas of $47,359.00 \mathrm{ha}$, or $65.19 \%$ of Manna watershed, andhigh risk of potential erosion with veryhigh sedimentation rate amounted to $248.851,1$ tons $\mathrm{yr}^{-1}$. In short, land cover in Manna watershed was generally in high environmental pressures, therefore, and in future, water resources would face environmental problems.
\end{abstract}

\section{Introduction}

A watershed as catchment areas plays important functions in human ecosystems [1]. In this ecosystem, human activities cultivated natural resources such as lands, water, vegetation and other biodiversities. In last decades, unwise usage on natural resources in watershed caused acceleration soil erosion hazard, degrading productivities on forest and agricultural land and sedimentation on river and lowland [2]. Depletion of watershed productivities today is mostly caused by mis management and poor coordination amongs take holders in controlling and managing natural and human resources within the watershed [3]. Manna watershed covers about $72.054,7 \mathrm{Ha}\left(720.54 \mathrm{~km}^{2}\right)$, consisting of upstream areas of $503 \mathrm{~km}^{2}$, middle-stream areas of $168.5 \mathrm{~km}^{2}$ and down-stream areas of $87,924 \mathrm{~km}^{2}$. The watershed lies from upstream in Lahat District, South Sumatra Province to downsteream in South Bengkulu.

Landscapes of Manna watershed mostly are rolling topographic with moderate to highly steep slope especially in the upstream areas having slope of 25-45 $\%$, or more than $45 \%$ [4]. Manna water shed also faces environmentally depletion caused by human activities.

Manna watershed facessome problems in relation to encroachment onprotected forest areas such as illegal logging, and traditional agricultural activities for coffee plantation. Agricultural activities on agricultural land on steep slope with coffee, rubber, and oil palm plantations are also done by traditional farming. Cultivation activities on Manna watershed, which neglected environmental aspects had caused severe land degradation widespread from upstream to down-stream areas as indicated by soil erosion on the top soil and river bank distributed along the Manna river bank. Furthermore, land degradation with high potential erosion decreased water quantity and quality on Manna River. In future, pressureon Manna watershed due to population increase and land demandcould threaten the balancing ecosystem for human life on this area such as risks of sedimentation, flooding, landslide, etc.

Soilerosionis carried by upstream run-off flowing to river systems, thensoil an-organic particles and organic materialis deposited on riverbed and suspended on the water [5]. The deposited materials causess hallowing drainage system on the river, therefore high intensity rainfall maycause river over flow . [6]. Because of these, flooding in the middle and down-stream occurred, and people living in the down-stream areas might face environmental disaster at anytime [7]. Based on the above problems, study of potential erosion hazard and sedimentation on Manna watershed was conducted.

The objective of this study is to analyze the erossion hazard level occuring on Manna river Basin and total sedimentation within the river.

\section{The materials and method}

This study was conducted on Manna watershed located between $102^{\circ} 51^{\prime} 38.2^{\prime \prime}-103^{\circ} 10^{\prime} 57.8^{\prime \prime}$ East., and $4^{\circ} 0^{\prime} 39.6^{\prime \prime}-$ $4^{\circ} 29^{\prime} 38.0^{\prime \prime}$ South, covering area of about $72.054,7$ ha as shown in figure 1 .

\footnotetext{
*Corresponding author: khairulftunib@yahoo.com
} 


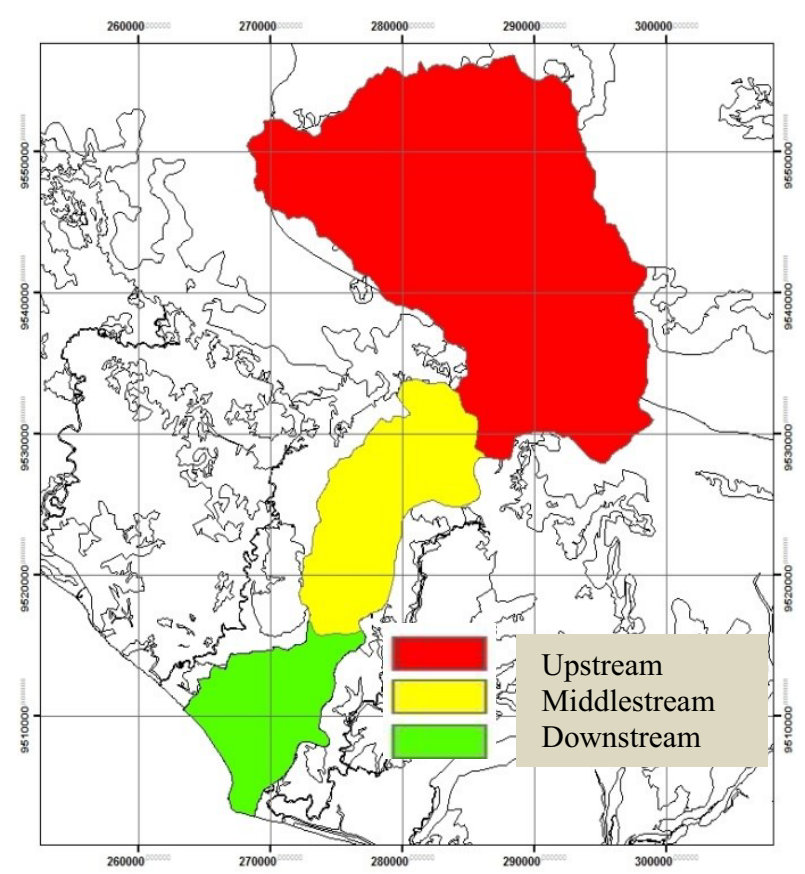

Fig. 1. Study location in Manna Watershed

Figure 1 shows the watershed comprising upstream, middle stream and downstream area.

Soil survey was conducted from May to July 2016 in order to collect soil samples, both disturbed and undisturbed soil samples. The soil samples were analyzed in Soil Science Laboratory, University of Bengkulu. The analysis of Soil characteristics include soil organic matter contents, soil textures, soil structures, and permeability.

Secondary data involved the last 10 year rainfall from The River Management Agency (Balai Wilayah Sungai) Sumatra VII, spatial data of land cover, land unit, topographical land slope, etc from Ketahun Watershed Management Office (BPDAS Ketahun), Bengkulu, Ministry of Environment and Forestry, Republic of Indonesia, and digital ALOS photos from Geospatial Information Agency, Republic of Indonesia.

Erosion is a process of soil removal or transport from one place to another one. The soil may be transported and eroded by wind or water.

Then, the transported soil is deposited in a river or stream . Erosion causes top soil loss which decreases soil absorbtion capacity .

There are a lot of models to predict erosion rate andUniversal Soil Loss Equation(USLE) is commonly used model to estimate erosion on a watershed.

Potentialsoilerosionwasestimatedusingempiricallybased USLE formula [9] :

$$
\mathrm{E}=\mathrm{R} \text { K LS C P }
$$

\footnotetext{
$\mathrm{E}=$ Potentialsoilerosion (tons $\mathrm{ha}^{-1} \mathrm{yr}^{-1}$ )

$\mathrm{R}=$ Erosivity index

$\mathrm{K}=$ Erodibility index

LS = Length and Slope indices

$\mathrm{C}=$ Crop Management Index

$\mathrm{P} \quad=$ Land Conservation Practice Index
}

Erosivity index (R) wascalculatedbased on the following equations [10];

$$
\mathrm{R}=2.21 . \mathrm{CH}^{1.36}
$$

Inwhich $\mathrm{CH}=$ rainfall.

Soilrodibility index (K)was calculated using formula as follows [11]:

$$
\begin{aligned}
100 K= & 1.292\left[2.1 M^{1.14} \times 10^{-4} \times(12-\alpha)+3.25(\mathrm{~b}-2)+2.5(\mathrm{c}-\right. \\
\text { Inwhich } & \\
\mathrm{M} & =\text { soil texture index } \\
\mathrm{M} & =[(\% \text { silt })+(100-\% \text { clay }] \\
\alpha & =\text { organicmatter content } \\
\alpha & =\left(\frac{100}{58} \times \mathrm{C} \text {-organic content }\right) \\
\mathrm{b} & =\text { soil structure } \\
\mathrm{c} & =\text { soilpermeability }
\end{aligned}
$$

LS factor was predicted according to Rules of Directorate General for Land Rehabilitation and Social Forestry, Ministry of Forestry, Republic of Indonesia No.P.4/V-SET/2013 [12]. Crop Management Index and Soil Conservation Practice Index followed published indices [13]. Visualisation and calculation of areas of soil erosion degrees was done by overlaying digital map of erosivity index $(\mathrm{R})$, erodibility index $(\mathrm{K})$, length and slope degree (LS), crop management (C), and soil conservation practice (P) using ArcGIS software.

GIS package has been used for carrying out geographic analysis. The GIS has beeen used for data analyses of Aereal photo data for deriving land cover characteristics.

Tolerable Soil Loss (TSL) was determined according topublished criteria. Total TSL was calculated using next equation:

$$
\text { Total TSL }=\text { TSL } \times \text { A }
$$

In which

$\mathrm{A}=$ watershed areas $\left(\mathrm{km}^{2}\right)$

The concept of Sediment Delivery Ration (SDR) is the process of transfering erosion to sedoment yield.

SDRis ratio between values of sedimentflowing to river and values of soilerosionyield onwatershed. Based on proposed formula [14], The concept of SDR was used to dertmine total sediment yield which can be expressed as the following :

$$
\mathrm{SDR}=-0.02+0.385 \cdot \mathrm{A}^{-0.2}
$$

In which

$\mathrm{A}=$ watershed areas $\left(\mathrm{km}^{2}\right)$

Then, sediment values (Y) was determined using next formula [15]:

$$
\mathrm{Y}=\mathrm{E}(\mathrm{SDR}) \mathrm{A}
$$

In which

$\mathrm{E}=$ Potential soil erosion (tons $\mathrm{ha}^{-1} \mathrm{yr}^{-1}$ )

The values of factors in USLE equation are usually computed according to Agricultural Handbook. The Rainfall Erosivity Index ( $R$ ) is calculated using an annual simulation of rainfall data using rainfall energy 30 minute duration. 
The yield of sediment is then estimated using Sediment delivery Ratio (SDR) which as function of Erosion and Watershed areas. The SDR concept is used to route surface erosion from catchment to the basin outlet.

\section{Results and discussion}

\subsection{Potential soil erosion level}

Erosivity index which wascalculated based on 10 year rainfall data over Manna watershed was 1,515.38. Soil lying on Manna watershed was catagorized into fairly high to very high level of erodibility class, therefore the soils wereprone to deteriorate when vegetative land cover wasdisclosed (Fig.2). Agricultural practices in Manna watershed should consider conservation values to avoid soil destruction on the land covering the watershed.

On the upstream of Manna watershed, landscape of the watershed was dominated by steep to very steep landslope (Fig. 3). Therefore, poor watershed management accelerated soil erosion on the upstream, and soil particles from the soil erosion would be deposited and shallowed riverbed on the down-stream of the Manna watershed.

Land use on the upstream of Manna watershed wasdominated by traditional agricultural activities with coffee plantation, and some parts on the upstream were covered by shrub and rubber plantation. Forest land coverwasfound only in some small areas in the border or in peak of hilly areas of the upstream Manna watershed.

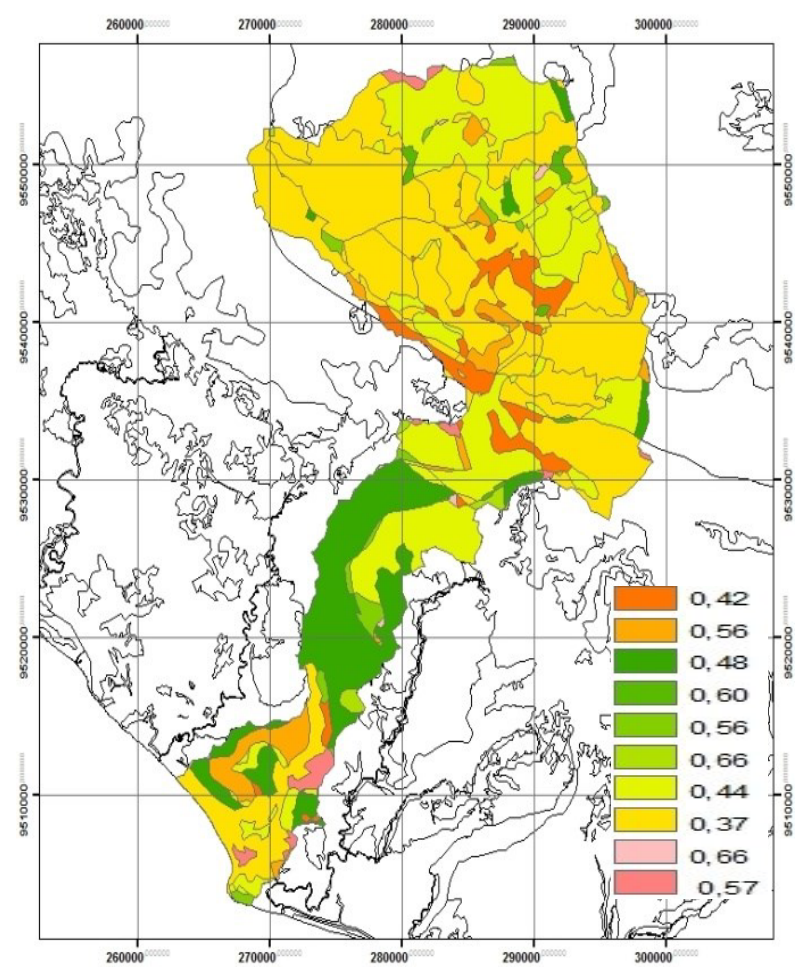

Fig. 2. Map of soil erodibility indices in Manna Watershed

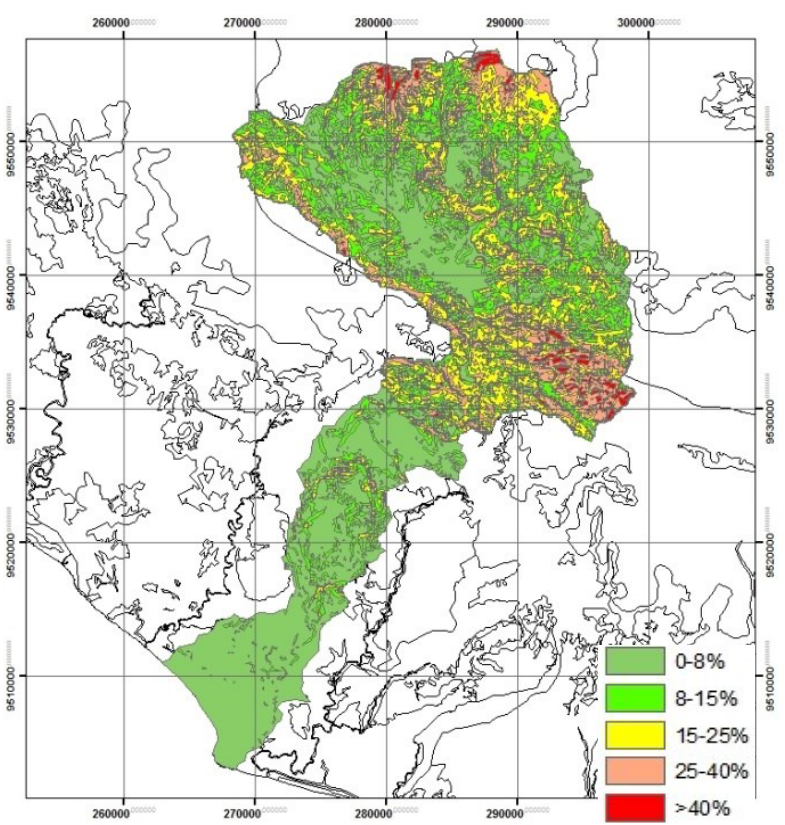

Fig. 3. Map of slope length and degree in Manna Watershed

Land use on the upstream of Manna watershed wasdominated by traditional agricultural activities with coffee plantation, and some parts on the upstream was covered by shrub and rubber plantation. Forest land cover was only found in some small areas in the border or in peak of hilly areas of the upstream Manna watershed (Fig. 4). Land management in the watershed was under poor conservation practices, especially in upland areas (Fig. 5). Some areas of protected forest in the upland today werecultivated as traditional perennial crops particularly coffee plantation.

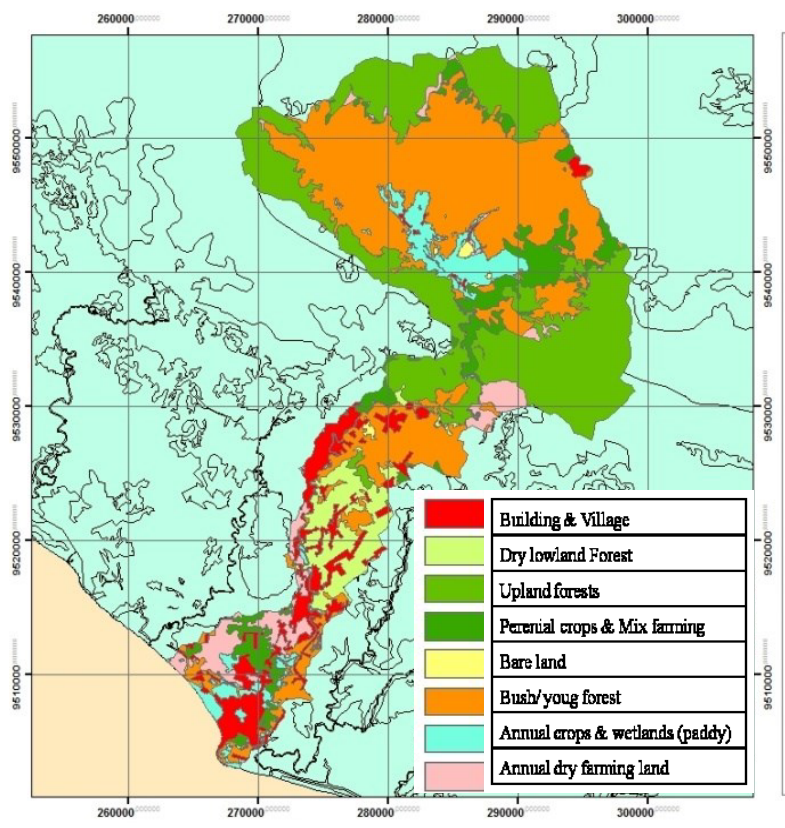

Fig. 4. Map of crop management in Manna Watershed 


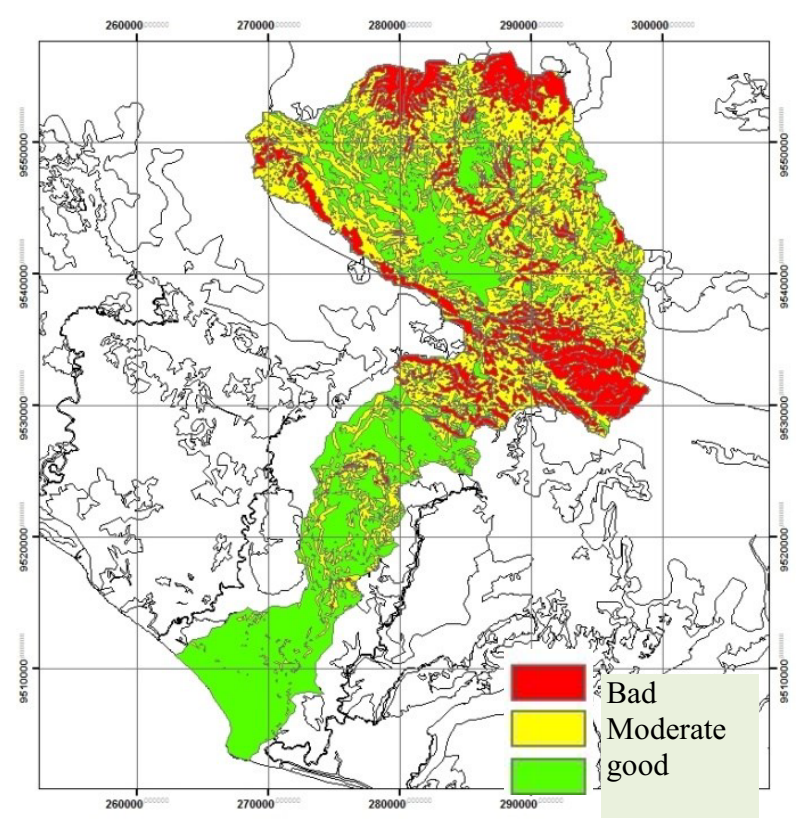

Fig. 5. Map of conservation practicesin Manna Watershed

Potential soil erosion which occurred in Manna watershed amounted to $12,442,368.12$ tons $\mathrm{yr}^{-1}$ or to average 170.68tons $\mathrm{ha}^{-1} \mathrm{yr}^{-1}$. In average, the potential soil erosion on Manna watershed was classified asmoderate erosion level. Potential soil erosion with very low potential erosion hazard, lower than 15 tons $\mathrm{yr}-1$ occurred in the areas of $6,036.29$ ha or $8.28 \%$ of the Manna watershed. Also, low erosion level of 15-60 tons $\mathrm{yr}^{-1}$ covered the area of $19,255.04$ ha or $26.41 \%$ of the watershed (Table 1). The low levels of erosion hazard covered only about $34.69 \%$. Therefore Manna watershed today undergoes deteriorated function for supporting human ecosystems.

The potential soil erosion in the level of moderate to very high covered about $47,608.57$ ha or $65.31 \%$. These hazardous levelwasdistributed mostly on upstream of the watershed (Fig. 6).

Table 1. Areas of the erosion hazard level in Manna watershed

\begin{tabular}{|c|c|c|c|}
\hline No & Erosion Level & Areas (ha) & (\%) \\
\hline 1 & Very Low & $6.036,29$ & 8,28 \\
\hline 2 & Low & $19.255,04$ & 26,41 \\
\hline 3 & Moderate & $19.655,14$ & 26,96 \\
\hline 4 & High & $19.497,94$ & 26,75 \\
\hline 5 & Very High & $8.455,49$ & 11,60 \\
\hline & Total & $72.899,9$ & 100 \\
\hline
\end{tabular}

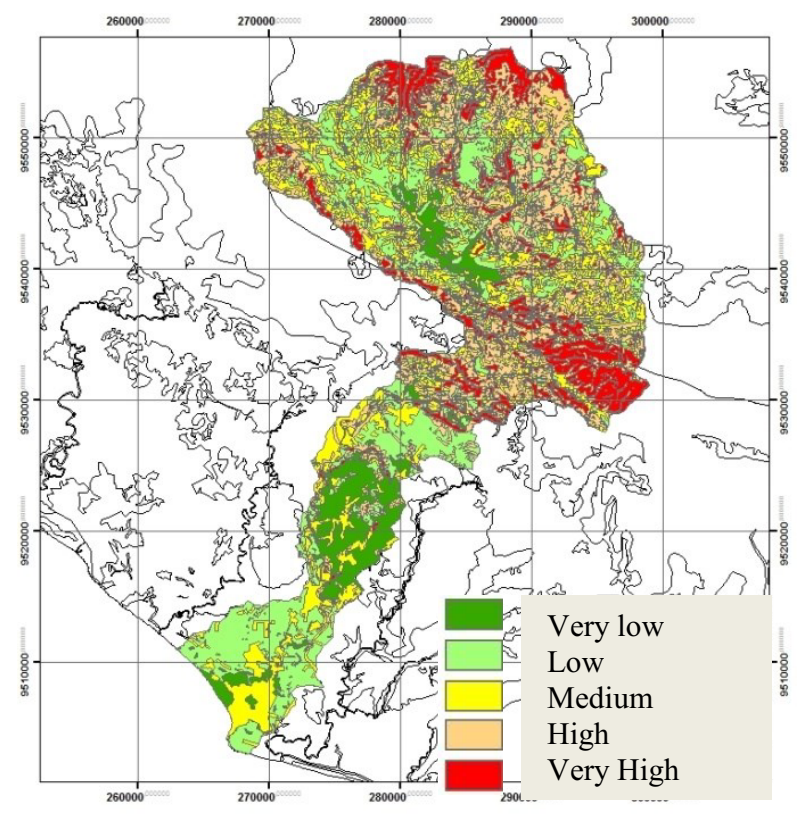

Fig. 6. Map of potential soil erosion level in Manna watershed

Considering sustainable function of ecosystem for human life in this area, the high potential soil erosion in the watershed is going to threaten sources of human life such as decreasing land productivities, water supplies for irrigation, and water qualities for water biotic ecosystems, etc.

\subsection{Sedimentation}

Sediment involved organic materials transported by water run-off and deposited on the riverbed and suspended on water flow. From the whole areas of Manna watershed, the SDR index was 0.02. This index was very small comparing to 1 , it means that whole potential sediments from lands flowed to Manna River, and was deposited to river bed or flowed to Indian Ocean. The total potential sediment flowing into Manna River was of $248.851,1$ tons $\mathrm{yr}^{-1}$, and this value was categorized ashigh level of sedimentation.

Tolerable sediment based on the value of total TSL and the value of SDR on the Manna watershed was about 19.610,07tons $\mathrm{yr}^{-1}$. Comparing the total potential sediments to the tolerable sediments, the potential sediments arebigger than permitted ones, therefore cultivation and management on Manna watershed especially on the upland should consider environmental values both land characteristics and water behavior as human ecosystems. The function of protected forestwhich wascultivated as traditional land agriculture for coffee plantation and bush has to be improved as protected forest areas. Collaborative land management with traditional villagers implementing social forestry might be as a wise solution to improve land productivities in Manna watershed. 


\section{Conclusions}

Based on analyses result and discussion, it can be concluded:

1. High Potential soil erosion in Manna watershed in high values is prone to deteriorate to be critical ecosystems.

2. Sedimentation flowing from upland polluting downstream of Manna River decreases water qualities in the whole downstream ecosystems.

3. Considering Manna watershed as a fragile ecosystem, agricultural practices should considerManna watershed as sustainable human ecosystems.

\section{References}

1. [1] H.Ramdan, Prinsip Dasar Pengelolaan Daerah Aliran Sungai. Forest Ecology Lab. Faculty of Forestry WinayaMukti University. Jatinangor, West Java.Indonesia (2006).

2. [2]H.Santoso. KebijakanPengelolaan DAS Terpadu.Director General of Watershed Management and Social Forestry, Ministry of Forestry.Coordination Meeting on Integrated Watershed Management.Batam. Indonesia. March 23( 2011).

3. [3]I.E.Soegiri. PeranPengelolaan DAS Terpadudalam Pembangunan Wilayah.Director for Planning and Evaluation of Watershed Management, Ministry of Forestry.Coordination Meeting on Integrated Watershed Management.Batam. Indonesia. March 23 (2011).

4. [4] BPDASKetahun, 2007, Karakteristik Daerah Aliran Sungai Manna Bengkulu. Watershed Management Agency Ketahun Bengkulu. Ministry of Forestry.Republic of Indonesia.BPDAS Ketahun, Bengkulu (2007).

5. [5] Sucipto. AnalisisErosi Yang Terjadi Di Lahan Karena Pengaruh Kepadatan Tanah.Wahana Teknik Sipil12, 1 pp 51-60 ( 2007).
6. [6] R. Setiaji. Pengaruh Kepadatan Tanah Terhadap Erosi yang terjadi di Lahan, Magister Thesis. Postgraduate Program.Gadjah Mada University. Yogyakarta. Indonesia( 2006).

7. [7] B.A. Kironoto. KonservasiLahan, GadjahMada University Press, Yogyakarta. Indonesia (2000).

8. [8] BWS Sumatera VII. Karakteristik Air Manna Bengkulu Selatan.River Management Agency (Balai Wilayah Sungai) Sumatera VII.Bengkulu.Indonesia (2012).

9. [9] W.H. Wischmeier and D.D. Smith. Predicting rainfal erosion losses, A guide to conservation planning.USDA. Agric. Handbook. 537. Washington DC (1978).

10. [10] J. Lenvain, M.DeBoodt and Suwardjo. An effective way in fighting soil erosion: promoting growth of young trees through plantpit treatment with soil conditioners. Mededelingen van de FaculteitLandbouwwetenshappenRijksuniversiteit Gent.41, 4 pp 141-157 (1976).

11. [11] W.H. Wischmeier. C.B. Johnson, and B.V. Cros. A soil erodibilitynomograph for farmland and construction sites.J. Soil and Water Conservation, pp.189-193. Sept-Oct (1971).

12. [12] Directorate General of Watershed Management and Social Forestry. PetunjukTeknisPenyusunan DataSpasialLahanKritis, Ministry of Forestry. 2013. www.dephut.go.id accessed in August 19 (2015).

13. [13] S. Arsyad. Konservasi Tanah dan Air, InstitutPertanian Bogor Press, Bogor.Indonesia (2010).

14. [14] K. Auerswald. Sensivitat erosions best immenderFaktoren. In: Wasser und Boden, 34-38. Verlag Paul Parey (1987).

15. [15] C. Asdak. HidrologidanPengelolaan Daerah Aliran Sungai, GadjahMada University Press, Yogyakarta.Indonesia (2002). 